\title{
Impact of Using Gadgets on Teenagers' Cognitive Development.
}

\author{
Billian Jawadi Lubis ${ }^{1}$, Dameria Sihite ${ }^{2}$, Tiurmauli ${ }^{3}$, Devi Herlina Tarigan ${ }^{4}$, Lestari \\ Perangin-angin $^{5}$ \\ \{jawadilubis@yahoo.com¹, dameriasihite151261@gmail.com²,tiurmaulipakam@gmail.com³, \\ dev89tarigan@gmail.com ${ }^{4}$, lestarinangin2016@gmail.com $\left.{ }^{5}\right\}$ \\ Postgraduate Program, Pelita Kebenaran School of Theology
}

\begin{abstract}
Abstrak. Technology is becoming increasingly sophisticated. One which has influenced the human mind is gadget. Gadgets offer a variety of interesting features and applications, adding appeal to all age groups. Apart from affecting the mindset as well as the behavior of adults, gadgets also affect the potential intellegence of adolescents. Gadgets are very helpful in life if appropriately and properly used. However gadgets can have a negative impact on people, particularly in children's cognitive development if used without parental supervision and direction. Teenagers basically tend to be enjoy new things that they can get from game-related activites. Playing games is fun for children and by playing games children can explore their potential. Most children in Indonesia spend time playing gadgets. As a result, this affects the development of children in a major way, especially in their cognitive development. Child cognition can be interpreted as intelligence potential consisting the phases of: knowledge, comprehension, application, analysis, synthesis, evaluation. Cognitive pertains to the ability to develop rational skills (reasoning). Nevertheless, in this case of the aspect of educators, cognitive development limits intelligence, knowledge of teenagers. The objective of this study is to see the negative impact of using Gadgets on cognitive development in adolescents. The research method used in this study is examining literature, namely by linking research with existing literature and inferrence based on previous research. By reviewing previous research, research hypothesis can be fomulted, as well as establishing indicators of justification of the importance of research to be conducted. The results of this study indicated that the use of gadgets by children in playing games reduces children's cognitive intelligence, especially at the teenage level. Children who initially enjoy playing with their friends can changeafter becoming habitual with gadgets as a substitute for playing with fruends. However, poor self-management and parental attention to children can create negative consequences.
\end{abstract}

Keywords: Gadgets, cognitive, negative impact, technology

\section{Introduction}

Gadgets are electronic devices that have highly sophisticated features provide convenience to people's lives. In Indonesia, children have become active users and so many electronic and gadget products are targeted to children as the market. There are plenty of cases today where children have developed a tendemcy to depend on the iPad. The child criesfuriously when his or her favorite gadget is taken away from his hand. This child can be said to have developed an addiction on one of the latest breakthroughs in this era of globalization. During eating, playing, 
studying and even when sleeping the child cannot be detached from the gadget. Most parents cannot do anything but obey the child's demand. Basicallychildren ate the age of teenagers should not yet become too familiar with gadgets as they still need more frequent interaction with friends of their age to play and create new things in their social environment and even in their family environment. The current study investigates the impact of gadgets onteenagres and its potential harm on them.

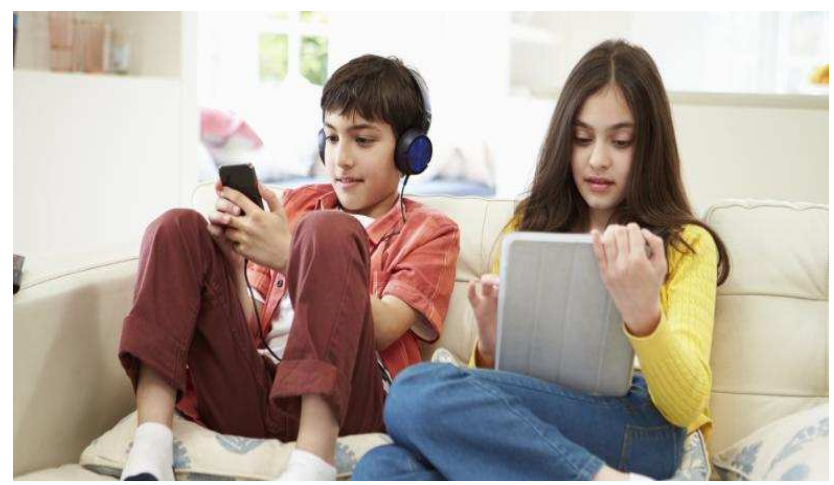

Figure 1. Negative Impact of gadget on teenagers (photo taken from Kompas.com - 10/10/2016)

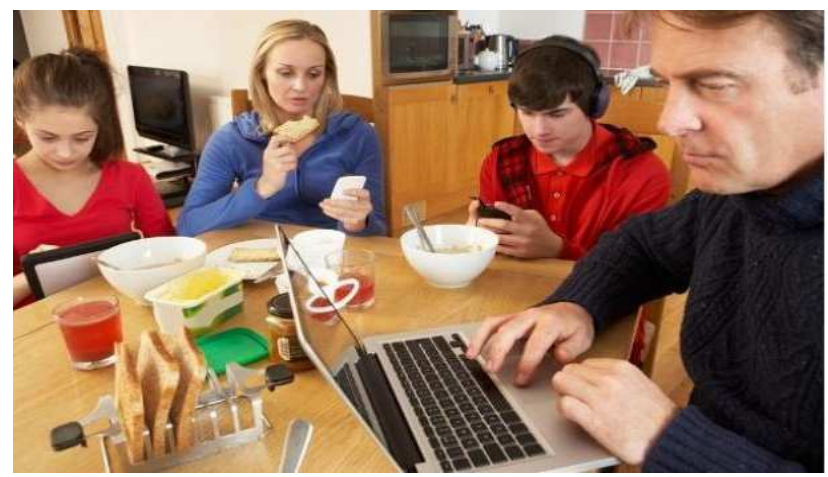

Figure 2. The result of being busy with everyone's gadget at the dining table (photo taken from Kompas.com - 30/09/2015)

Gadgets Potentially make children quickly satisfied with the knowledge they get so that what they get from the internet or other technology is the most complete and final knowledge. The result is that children are increasingly weak in terms of patience and concentration and are quick to demand people to give what they want immediately. Early childhood to teenagers is a sensitive period for various aspects of development, i.e., early development of physical, language, social emotional, and cognitive abilities. According to Piaget, children have 4 levels of cognitive development, namely the sensory motor stage ( $0-2$ years), concrete pre-operational (2-7 years), concrete operations (7-11 years), and formal operations (11 years and over). Characteristics of early childhood are individuals who have a level of development that is relatively quick to react everything from various aspects of development that exist.

If the children are already addicted and are negatively affected by the gadget, the cognitive development of children will be hampered. Without realizing it without directed and integrated guidance from parents and family, children's development will lead to the negative 
consequences. The following is a description of the damage to the brain development of adolescents as a result of gadget addiction.

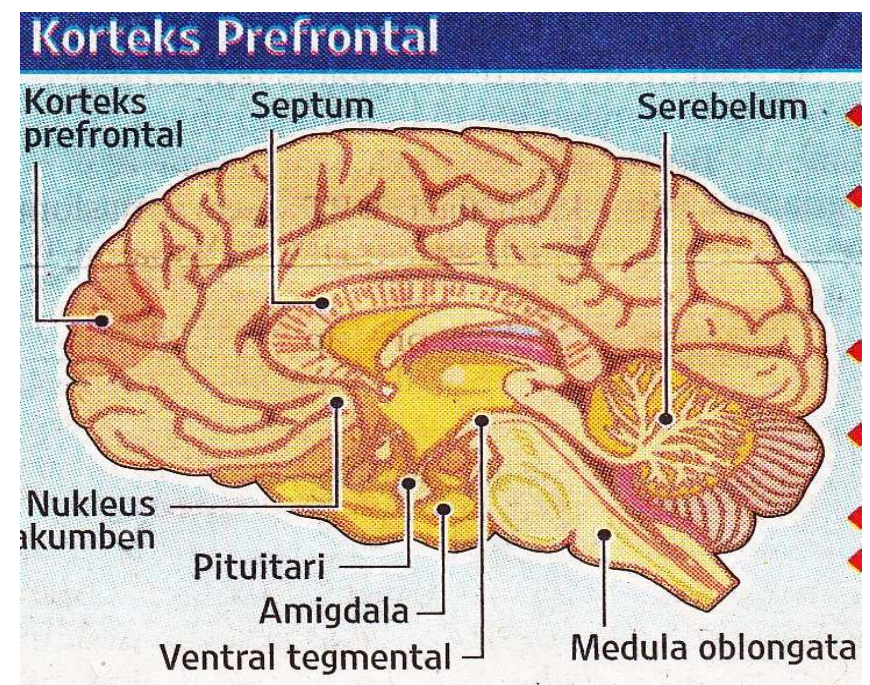

Function:

- Emotion control function

- Impairment causes negative behavior change

- Associated with aggressive behavior

- Left: anxiety and fear

- Right: cheerful

- Decision making and intuition function

Fig. 3. Brain Impairment caused by gadget addiction difficult to heal

The human brain has been found decrease in function caused by intense use of gadgets. If one is unable to prevent addictive behavior, the effect is a feeling of being offended or anger if the activity is stopped. According to Dr. Donald Hilton Jr. brain impairment caused by addiction is more difficult to heal than addiction to eating (obesity) and drugs. In general, the brains of gadget addicts will produce dopamine and endorphin which are brain chemicals that create a feeling of happiness and feeling better. If the habit of this gadget is excessive, then the brain will experience hyper excessive stimulation that affects the performance of neurotransmitters or brain chemicals that send messages. Allowing extensive enjoyment of this habit can be fatal, namely the shrinkage of brain tissue because it continues to work and gradually the brain will experience permanent decrease in volume and even damage. Brain shrinkage can be reversed to normal if the treatment is intense, requiring treatment for at least aound 1.5 years. Because basically the brain continues to experience tissue regeneration, thus, the shrinking brain can come back again. However, eventually the recovery depends on the case of addiction suffered. Based on a survey by an observer of the impact of gadgets on children at one of the school foundations in Pekan Baru, the results were very surprising, namely that most children up to teenagers use gadgets just to watch, and play games, apparently describing giving more positive impact on cognitive development in early childhood to teenagers.

Table 1. Percentage of gadget use impact in a Pekanbaru School Foundation 2016 
$\overline{\text { Gadget use impactRespondentPersentage }}$

\begin{tabular}{|c|c|c|}
\hline Positive & 31 & 51.7 \\
\hline Negative & 29 & 48.3 \\
\hline Total & 60 & 100 \\
\hline
\end{tabular}

Based on the table above, out of 60 respondents, for 31 people $(51.7 \%)$ the impact of using the gadget is positive; the positive impact seen in children in the form of easy to obtain information related to education such as recognizing color and language, making children more creative and active school and in a residential environment. For 29 people (48.3\%) the impact of using gadgets is negative, this shows that children are more likely to be angry, hyperactive and like to win the game with their friends and other negative effects that children develop include faster adaptaion to technology, causing children to be submerged in technological sophistication, oblivious of their surrounding environment, prefering instead to play gadgets rather than playing with friends and the environment around their residence. This ultimately results ina decrease and degradation in social communication between children and the community.

\section{Parents' expectations of children}

Every parent has hopes of having a good, intelligent children who are also focused on their future. The hope of parents is to have children who experience development according to their growth. This means that the development of teenagers whose schools aim to give students direction according to their development.

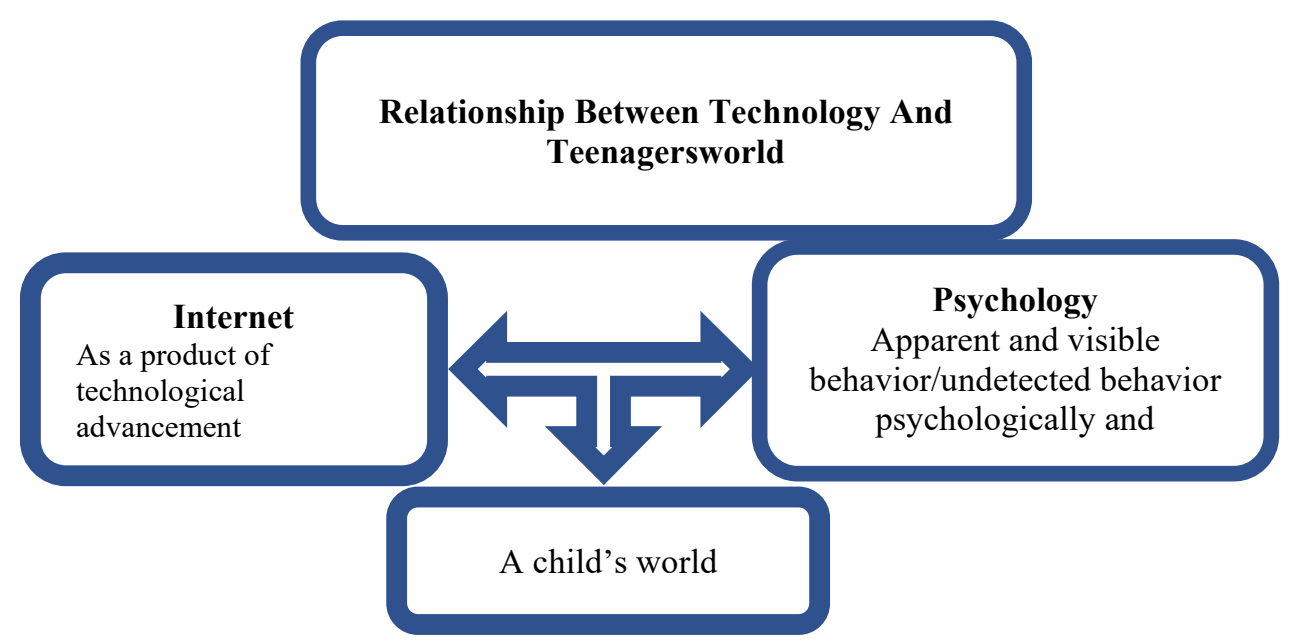

Fig.4. Relationship between technology and teenagers world

\section{Research Result}


Addiction to gadgets by children is caused by the duration of time of exposure. Playing games using gadgets in a relatively long duration of time on a daily basis can develop or triggerantisocial behavior among. The consequences of such conditions is that it makes children individualistic because they eventually neglect to communicate and interact with the surrounding environment.

According to Maulida (2013) the signs of early childhood addicted to gadgets:

- $\quad$ Loss of desire to be physically active;

- Continuously talking about technology;

- Tendency to refuse instructions if they implicated a separation from the gadget;

- $\quad$ Easy to get offended, causing unstable mood changes;

- Selfishness or unwillingness to share gadget with other people;

Compulsive lying lying because as they are unseparable from the gadget, meaning that they will look for any way to still be able to use the gadget even though it deprives sleeping time. Finallyit ccauses a decreases the level of intelligence from early childhood to adolescents. Evidence for this notion has been explained in the introduction above concerning how a child's brain becomes smaller as he or she develops an addiction to gadget use.

\section{Conclusion}

This causes various kinds of influences on the pattern of human life, both thought patterns and behavior. Technology is the whole means to provide goods needed for the survival and comfort of human life. One of the technological developments that greatly influences the human mindset is gadgets. Gadgets are media that are used as modern communication tools. Gadgets make it easier for human communication activities. Now communication activities have developed more and more advanced with the advent of gadgets. One of them affects social interaction in early childhood.

\section{Suggestion}

1) Further research is needed on the impact of using gadgets on cognitive development in adolescents.

2) This research is conducted quantitatively, so it is expected that the next researcher can find inormation directly to parents, teachers and students qualitatively.

3) The role of the School also has a big contribution to be able to provide guidance to children about the dangers of gadgets and rules in their use, considering that all the teacher's sayings are more heard and understood by children.

4) It is hoped that there will be collaboration between the school and parents to collaborate with each other in monitoring children's development.

\section{Refference}

Anggrahini, 2013. Dinamika komunikasikeluarga penggna gadget, Universitas Ilsma Negeri Sunan Kalijaga, Fakultas Ilmu Sosial dan Humaniora. Yogyakarta.

Iis, Hendra, Edy, 2014. Pengaruh penggunaan gadged terhadap daya kembang anak (Prosiding SeminarNasional Multidisiplin Ilmu)Jakarta : Universitas Budi Luhur. 
Sagala, syaiful. 2004. Konsep \& maknapembelajaran. Bandung : alfabeta.

Manumpil,dkk. 2012. HubunganPenggunaan Gadget Dengan Tingkat Prestasi Siswa Di SMA Negeri 9 manado (Online), e-journal keperawatan(e-Kep) Volume 3 Nomor 2 April 2015.

Muh F. 2013. Pengaruh gadged terhadap perkembangan anak usia dini. Surabaya : Teknik Informatika, Universitas Brawijaya PTIIK.

Fitra Mayenti, Indiana Sunita.Dampak Penggunaan Gadget Terhadap Perkembangan Anak Usia Dini, Jurnal PhotonVol. 9. No. 1, Oktober 2018

Putri Hana Pebriana, Analisis Penggunaan Gadget terhadap Kemampuan Interaksi Sosial pada Anak Usia Dini, Jurnal Obsesi Volume 1 Nomor 1 Tahun 2017 Halaman $1-11$.

Maya Ferdiana Rozalia, Hubungan Intensitas Pemanfaatan Gadget Dengan Prestasi Belajar Siswa, Jurnal Pemikiran Dan Pengembangan Anak, Volume 5, Nomor 2, September 2017

Amelia Vinayastri, Pengaruh Pola Asuh (Parenting) Orang-Tua Terhadap Perkembangan Otak Anak Usia Dini, Universitas Muhammadiyah Prof. Dr. Hamka.

Ida Karismatika, Laporan Kasus:Terapi Kognitif Perilaku Untuk Remaja Dengan Gangguan Tingkah Laku, Jurnal Sains Danpraktik sainspsikologi, 2014, Volume 2 (3), 296-301. 